\title{
Effect of feeding of chelating agent to reduce risk of aflatoxicosis on blood characteristics and milk quality of cows
}

\author{
M.G. Kokaeva ${ }^{1 *}$, R.B. Temiraev ${ }^{1,2}$, Y.A. Yuldashbaev ${ }^{3}$, K.B. Temiraev ${ }^{1}$, \\ L.A. Bobyleva ${ }^{4}$, G.F. Dzhioeva ${ }^{2}$, D.Yu. Petrushkin ${ }^{5}$
}

${ }^{1}$ North-Caucasian Mining and Metallurgical Institute (State Technological University), Vladikavkaz 362021; ${ }^{2}$ Gorsky State Agrarian University, 362040, Vladikavkaz, 37 Kirov Street, ${ }^{3}$ Russian State Agrarian University - Moscow agricultural Academy after K.A. Timiryazev, Moscow 127550; ${ }^{4}$ North-Ossetian State University named after K.L. Khetagurov, Vladikavkaz, 362025; ${ }^{4}$ Federal Science Center for Animal Husbandry named after Academy Member L.K. Ernst 142132,Moscow region, Podolsk City district, Dubrovitsy settlement, house 60, Russian Federation.

*Corresponding author E-mail: k-marina85@inbox.ru

Journal of Livestock Science (ISSN online 2277-6214) 12: 336-340

Received on 3/10/21; Accepted on 10/11/21; Published on 8/12/21

doi. 10.33259/JLivestSci.2021.336-340

\begin{abstract}
The solution to the problem of increasing the productivity and quality of cow milk at the risk of aflatoxicosis is the use of feed additives that can provide detoxification of these toxicants. One of the technological methods of reducing the negative impact on the processes of tissue metabolism, ensuring the environmental milk safety is feeding the complex (chelate) compounds that have sorption-active properties. The research aims to study the effect of chelate preparation ferrocene at a dose of $0,4 \%$ by feed weight as a part of diets with high content of aflatoxin $\mathrm{B}_{1}$, the concentrates basis of which were corn, barley and soybean, on some indicators of intermediate metabolism and productivity in lactating cows. Analysis of the resulting data shows that the density of cow milk in the compared groups was within the normal range 27,85 and $28,30^{\circ} \mathrm{A}$ with the significant difference in favor of the animals in the test group $(\mathrm{P}<0,05)$. The milk acidity in the control group was $17,80^{\circ} \mathrm{T}$, and of the cow milk in the test group $-17,75^{\circ} \mathrm{T}$, i.e. in this indicator they had practically no differences. The level of aflatoxin $\mathrm{B}_{1}$ detoxification in bodies of experimental animals was closely related to the ascorbic acid retention and retinol synthesis in the liver from carotene of feed. Due to this, cows in the test group had a higher concentration of vitamins $\mathrm{A}$ and $\mathrm{C}$ in their blood serum, having significantly $(\mathrm{P}<0,05)$ surpassed the control in these indicators by 2,93 and 2,11 times.Cows of the control group had 2,87 $\mathrm{mg} \%$ of albumins in their blood, cows of the test group - $0,33 \mathrm{mg} \%$ more. According to $\gamma$-globulins content in the blood serum, animals of the test groups exceeded the control by $0,23 \mathrm{mg} \%$, which indicates the favourable effect of the preparation ferrocene on the resistance of cows.
\end{abstract}

Keywords: dairy cattle;mycotoxins; chelate supplement; milk composition; blood morphology, biochemical composition 


\section{Introduction}

The main task in the milk production is to provide the population with dairy products that have high environmental nutritional qualities, because preservation of people's health and efficiency depends largely on the quality of consumed products, including animal products. Mycotoxins, fungi poisons in the cows body greatly influence the productivity, physico-chemical and technological properties of dairy products. Among mycotoxins, aflatoxins produced by microscopic fungi Aspergillusflavus and Aspergillusparasiticus stand out for their toxic properties. When the most widely distributed aflatoxin $B_{1}$ is ingested into the dairy cows' diet with milk its metabolite aflatoxin $M_{1}$ can be extracted (Tedtovaet al., 2013; Vityuket al., 2012; Kairovet al., 2020; Temiraevet al., 2017; Tsalievaet al., 2017; Hamikoevaet al., 2021).

The solution to the problem of increasing the productivity and quality of cow milk at the risk of aflatoxicosis is the use of feed additives that can provide detoxification of these toxicants. One of the technological methods of reducing the negative impact on the processes of tissue metabolism, ensuring the environmental milk safety is feeding the complex (chelate) compounds that have sorption-active properties (Temiraevet al., 2015; Temiraevet al., 2017; Chokhataridiet al., 2012; Yuldashbaevet al., 2021).

The term «chelate» is of Greek origin, meaning the word «crab». Chelate compounds bind various toxic substances (toxicant molecules are captured from two ends, like crab by its claws), forming chelate complexes and remove them from the body with urine through the kidneys. Therefore, preparations of chelate nature are increasingly used as detoxifiers of mycotoxins, nitrates, nitrites and other toxicants. This factor promotes interest in chelate feed additives of new generation, in the structure of which macro- and microelements are represented in the form of a complex with bioligands(Temiraevet al., 2017; Kokaevaet al., 2020; Temiraevet al., 2011;Temiraevet al., 2020).

The research aims to study the effect of chelate preparation ferrocene at a dose of $0,4 \%$ by feed weight as a part of diets with high content of aflatoxin $\mathrm{B}_{1}$, the concentrates basis of which were corn, barley and soybean, on some indicators of intermediate metabolism and productivity in lactating cows.

\section{Material and Methods}

To solve the problem scientific and economic experiment according to the scheme presented in Table 1 was conducted on Swiss cows in the agricultural production cooperative «Myasoprodukty», RNO - Alania.

20 cows selected due to their origin, age at calving, live weight, date of the last insemination, productivity for the previous lactation and the fat content in milk, were divided by the analogue scale into 2 groups of 10 animals each. According to the experiment scheme, the cows in the control group were fed the basic diet (BD), and the animals of the test group - BD supplemented with chelate preparation ferrocene at a dose of $0.4 \%$ by feed weight.

FERROCEN (Prussian Blue) - the main active ingredient, which is an agglomerate of dark blue nanoparticles. Produced by NPP Eksorb (Russia) Getting into the gastrointestinal tract of animals FERROCEN (Prussian Blue) forms a colloidal system of nanoparticles with a huge surface area and sorption activity. Ferrocen colloids form strong complexes with toxic microelements that are unable to penetrate the mucous membrane of the alimentary canal. Possessing unique sorption characteristics, ferrocen selectively removes heavy toxic metals (cadmium, lead, mercury, thallium, etc.) and hazardous radionuclides from various media.In the diet structure, $31 \%$ fell to the share of concentrates that were represented by corn, barley and soybean. By their step-by-step mixing with the help of dispensers, the content of aflatoxin $B_{1}$ in the diets of experimental cows at a dose of $20 \mathrm{mg} / \mathrm{kg}$ of the diet dry matter was gained.

Dairy productivity of cows was determined on the basis of control milk yields held once a decade. During the days of control milk yield, the content of fat and protein, as well as other organic and mineral substances in experimental cows milk was determined by conventional methods. To characterize the metabolic processes in the body and cows physiological state, morphological and biochemical parameters of cows were studied by conventional methods.Quantitative determination of aflatoxin $B_{1}$ in feed and aflatoxin $M_{1}$ in milk was carried out by conventional methods.

The experimental material was statistically processed by Student's t-test using application programs software package SNEDECOR.

\section{Results and Discussion}

To study the efficacy of aflatoxin $\mathrm{B}_{1}$ detoxification by using the adsorbent ferrocene, we identified indicators of milk productivity and some physico-chemical parameters of cow milk (Table 2).

When comparing the indicators of actual milk yield, it is clear that cows of the control group yielded $111 \mathrm{~kg}$ less milk per lactation compared to the test group, although the difference during the statistical processing was insignificant $(\mathrm{P}>0.05)$.

Analysis of the resulting data shows that the density of cow milk in the compared groups was within the normal range 27.85 and $28.30^{\circ} \mathrm{A}$ with the significant difference in favor of the animals in the test group. The difference is 
statistically significant $(\mathrm{P}<0.05)$. The milk acidity in the control group was $17.80^{\circ} \mathrm{T}$, and of the cow milk in the test group $-17.75^{0} \mathrm{~T}$, i.e. in this indicator they had practically no differences.

Table 1 - Scheme of scientific and economic experiment on cows $(n=10)$

\begin{tabular}{|l|l|}
\hline \multicolumn{1}{|c|}{ Groups } & \multicolumn{1}{c|}{ Feeding habits } \\
\hline Control & Basicdiet with a tolerant level of aflatoxins (BD) \\
\hline Test & BD + chelate preparation ferrocene at a dose of $0.4 \%$ by feed weight \\
\hline
\end{tabular}

Table 2- Milk yield and physico-chemical properties of experimental cow milk $(\mathrm{n}=10)$

\begin{tabular}{|c|c|c|}
\hline \multirow{2}{*}{ Indicator } & \multicolumn{2}{|c|}{ Group } \\
\hline & control & test \\
\hline Milk yield, kg & $5631 \pm 74.27$ & $5742 \pm 91.80$ \\
\hline Density, $A^{0}$ & $27.85 \pm 0.12$ & $28.30 \pm 0.016$ \\
\hline Acidity, $\mathrm{T}^{0}$ & $17.80 \pm 0.11$ & $17.75 \pm 0.12$ \\
\hline Dry matter, $\%$ & $12.22 \pm 0.11$ & $12.66 \pm 0.09$ \\
\hline Milkfat, $\%$ & $3.56 \pm 0.08$ & $3.79 \pm 0.06$ \\
\hline Skim solids, \% & $8.66 \pm 0.04$ & $8.97 \pm 0.04$ \\
\hline Milk protein, $\%$ & $3.22 \pm 0.08$ & $3.41 \pm 0.07$ \\
\hline Lactose, $\%$ & $4.69 \pm 0.07$ & $4.69 \pm 0.06$ \\
\hline Ash, \% & $0.75 \pm 0.01$ & $0.77 \pm 0.006$ \\
\hline Calcium, $\%$ & $0.17 \pm 0.006$ & $0.17 \pm 0.002$ \\
\hline Phosphorus, \% & $0.11 \pm 0.002$ & $0.12 \pm 0.003$ \\
\hline Carotene, $\mathrm{mg} \%$ & $0.146 \pm 0.003$ & $0.155 \pm 0.006$ \\
\hline Aflatoxin $_{1}, \mathrm{mg} / \mathrm{l}$ & $244.32 \pm 0.003$ & $122.21 \pm 0.002$ \\
\hline
\end{tabular}

Table 3 - Morphological parameters of cows blood ( $\mathrm{n}=3$ )

\begin{tabular}{|l|c|c|c|}
\hline \multirow{2}{*}{\multicolumn{1}{|c|}{ Indicator }} & \multicolumn{3}{c|}{ Group } \\
\cline { 2 - 4 } & Control & test & \% to the control \\
\hline Erythrocytes, $10^{12} / 1$ & $5.97 \pm 0.20$ & $7.43 \pm 0.19$ & 124.4 \\
\hline Leukocytes, $10^{9} / 1$ & $10.16 \pm 1.12$ & $10.08 \pm 1.46$ & 99.2 \\
\hline Hemoglobin, $\mathrm{g} / \mathrm{l}$ & $96.5 \pm 2.2$ & $116.0 \pm 2.4$ & 120.2 \\
\hline
\end{tabular}

Table 4 - Blood biochemistry of experimental cows ( $n=3)$

\begin{tabular}{|l|c|c|c|}
\hline \multirow{2}{*}{\multicolumn{1}{c|}{ Indicator }} & \multicolumn{3}{|c|}{ Group } \\
\cline { 2 - 4 } & control & test & \% to the control \\
\hline Total protein, $\mathrm{g} / \mathrm{l}$ & $72.3 \pm 0.71$ & $77.5 \pm 0.62$ & 107.2 \\
\hline Sugar, $\mathrm{mmol} / \mathrm{l}$ & $2,45 \pm 0.12$ & $3.30 \pm 0.26$ & 134.7 \\
\hline Calcium, $\mathrm{mmol} / \mathrm{l}$ & $9.21 \pm 0.60$ & $9.33 \pm 0.52$ & 101.3 \\
\hline Phosphorus, $\mathrm{mmol} / \mathrm{l}$ & $4.81 \pm 0.39$ & $4.89 \pm 0.46$ & 101.6 \\
\hline Acetone, $\mathrm{mmol} / \mathrm{l}$ & $0.44 \pm 0.02$ & $0.18 \pm 0.04$ & 40.9 \\
\hline Vitamin A, mmol/l & $0.15 \pm 0.003$ & $0.44 \pm 0.003$ & 293.3 \\
\hline Vitamin $\mathrm{C}, \mathrm{mmol} / \mathrm{l}$ & $1.21 \pm 0.007$ & $2.56 \pm 0.012$ & 211.6 \\
\hline
\end{tabular}

Table 5 - Content of total protein and protein fractions in blood serum of the experimental cows, $\mathrm{mg} \%(\mathrm{n}=3)$

\begin{tabular}{|c|c|c|}
\hline \multirow{2}{*}{ Indicator } & \multicolumn{2}{|c|}{ Group } \\
\cline { 2 - 3 } & control & test \\
\hline Total protein & $8.08 \pm 0.60$ & $8.44 \pm 0.52$ \\
\hline Including: albumins & $2.87 \pm 0.29$ & $3.20 \pm 0.40$ \\
$\alpha$-globulins & $1.51 \pm 0.14$ & $1.36 \pm 0.29$ \\
$\beta$-globulins & $1.04 \pm 0.12$ & $1.06 \pm 0.11$ \\
$\gamma$-globulins & $2.56 \pm 0.25$ & $2.79 \pm 0.30$ \\
\hline Protein ratio(A/G) & 0.56 & 0.61 \\
\hline
\end{tabular}

The use of chelate preparation ferrocene at a dose of $0.4 \%$ by feed weight in dairy cattle diets with an increased dose of aflatoxin $\mathrm{B}_{1}$ contributed to promote the level of milk protein. Due to this, the protein content in the milk of the test group was $0.19 \%$ higher than in the control group, which was statistically significant $(\mathrm{P}<0.05)$. The difference is statistically significant $(\mathrm{P}<0.05)$. 
The introduction of chelate preparation ferrocene at a dose of $0.4 \%$ by feed weight into the cows diets of the test group contributed to enrich their milk in dry matter, the content of which in the milk of the test group was significantly $(\mathrm{P}<0.05)$ 0.44\% higher compared to the control. Ash fluctuations in the milk of experimental animals averaged within the experiment $0.75-0.77 \%$. The cows of the compared groups had practically no difference in lactose and calcium content in milk. At the same time, compared to the control $(\mathrm{P}<0.05), 0.02 \%$ higher content of phosphorus was recorded in the milk of the test group.With the introduction of the preparation ferrocin in an amount of $2 \mathrm{~g} / 100 \mathrm{~kg}$ of live weight in cows of the experimental group, an increase in the content of fat and protein in milk was observed, while a decrease in zinc, cadmium and lead was observed (Tedtovaet al., 2013).

Aflatoxins, as dangerous toxicants, significantly reduce the consumer properties of milk and dairy products. Milk of cows in the control group contained $4.32 \mathrm{mg} / \mathrm{l}$ of these toxicants. The preparation ferrocene supplements to the diets of animals in the test group contributed versus the control to reduce aflatoxin $\mathrm{M}_{1}$ in their products by 2.09 times $(\mathrm{P}<0.05)$. The difference is statistically significant $(\mathrm{P}<0.05)$. When aflatoxin $\mathrm{B}_{1}$ is found in feed hematological parameters undergo significant changes, on the basis of which, the blood morphology in the experimental cows was studied (Table 3 ).

The stimulating effect of the preparation ferroceneon protein metabolism had a positive impact on the hematopoietic function of the cows body in the test group, thereby they, versus the control, had significantly $(\mathrm{P}<0.05)$ more than $24.4 \%$ of erythrocytes and $20.2 \%$ of hemoglobin in the internal liquid medium. Along with the morphology, some biochemical blood parameters were studied (Table 4).It was found that the tested chelate preparation had no real effect on the mineral metabolism in the body, as evidenced by the data of calcium and phosphorus concentration in the blood serum.

The level of aflatoxin $\mathrm{B}_{1}$ detoxification in bodies of experimental animals was closely related to the ascorbic acid retention and retinol synthesis in the liver from carotene of feed.Due to this, cows in the test group had a higher concentration of vitamins $\mathrm{A}$ and $\mathrm{C}$ in their blood serum, having significantly $(\mathrm{P}<0.05)$ surpassed the control in these indicators by 2.93 and 2.11 times. The difference is statistically significant $(\mathrm{P}<0.05)$.Energy metabolism in cows of the test group during the process of aflatoxins detoxification, was also activated, as evidenced by significantly $(\mathrm{P}<0.05)$ higher glucose concentration in blood serum $-34.7 \%$ more versus the control.Our data are consistent with the results of a number of scientists (Chokhataridiet al., 2012), who, when feeding ferrocene to reduce the risk of aflatoxicosis, were able to achieve an increase in the blood content of vitamins A and C.

Ratio of total protein and acetone in serum, which depended inversely in the blood of experimental animals, may indicate the imbalance of protein metabolism. When feeding the preparation ferrocene cows in the test group experienced the optimization of protein metabolism (Table 5), thereby their serum versus the control contained significantly $(\mathrm{P}<0.05)$ $7.2 \%$ more total protein and $59.1 \%$ less acetone $(\mathrm{P}<0.05)$. The difference is statistically significant $(\mathrm{P}<0.05)$. Blood serum proteins perform various functions in the body. The content of protein in the blood serum and its fractions - albumins and globulins characterizes the level of protein metabolism in animals. When feeding the preparation ferrocene during the experiment, the total protein content has increased on average in the blood of animals. Analyzing the fluctuations of protein fractions, there was the tendency of increasing $\gamma$-globulin albumins in blood serum due to adsorbent supplements to the diets. Cows of the control group had $2.87 \mathrm{mg} \%$ of albumins in their blood, cows of the test group $-0.33 \mathrm{mg} \%$ more. According to $\gamma$-globulins content in the blood serum, animals of the test groups exceeded the control by $0.23 \mathrm{mg} \%$, which indicates the favourable effect of the preparation ferrocene on the resistance of cows.During the experiment, when feeding the chelate preparation ferrocene, it was possible to increase the concentration of total protein in the blood of black-andwhite cows and optimize its fractions (Kairovet al., 2020). The increase of protein ratio also indicates the increase of albumin fraction in relation to globulin. The dynamics of total protein content and its fractions in the blood serum of cows shows the superiority of animals in the test group over the control group.

\section{Conclusion}

To improve milk productivity, physico-chemical properties of milk and improvement of blood morphology and biochemistry in lactating cows chelate preparation ferrocene at a dose of $0.4 \%$ by feed weight should be included in their diets with a high background of aflatoxin $B_{1}$.

\section{References}

1) Chokhataridi G.N., Vityuk L.A., Salbieva F.T., Payuchek V.G. 2012. Nutritional value of broilers meat at the risk of aflatoxicosis.Meat industry. 4: 59-61.

2) Hamikoeva S.R., Temiraev R.B., Chabaev M.G., Tsis E. Yu., Gappoeva V.S., Khabaeva Z.G., Gagloeva A.R. 2021. Effect of adsorbent and enzyme preparations on productivity of fattening steers with diets containing heavy metals. Journal of Livestock Science 12: 60-64. doi. 10.33259/JLivestSci.2021.60-64.

3) Kairov V.R., Kairov A.V., Chabaev M.G., Nekrasov R.V., Temiraev K.B., Tsagaraeva E.F., Bobyleva L.A. 2020. The influence of antioxidant on the productivity and activity of digestive broiler enzymes in reducing the risk of T-2 toxin.Journal of Livestock Science 11: 85-89.doi. 10.33259/JLivestSci.2020.85-89. 
4) Kokaeva M.G., Temiraev R.B., Dzhaboeva A.S., Osikina R.V., Gazzaeva M.S., Shugusheva L.H., Sattsaeva I.K., Nerovnykh L.P., Arutyunova G.Y., Efendiev B.S. 2020. Method for increasing the ecological and food values of milk and dairy products. Journal of Livestock Science 11: 14-19 doi. 10.33259/JLivestSci.2020.14-19.

5) Tedtova V.V., Baeva, Z.T., Dzodzieva, E. S., Tsopanova, Z.Ya. andPilov, A.Kh. 2013. Meat productivity of the calves of different breeds, raised in the industrial zone. Meat Industry. 3: 60-62.

6) Temiraev R.B.,Baeva A.A., Ktsoeva I.I., Vityuk L.A., Titarenko E.S., ,Buglenko A.G. 2015. Improvement of feeding conditions encourages greater productivity and metabolism of broilers. Proceedings of Gorsky state agrarian university. 52, - №4: 138-143.

7) Temiraev R.B., Kozyrev S.G., Kononenko S.I., Baeva A.A., Bobyleva L.A., Kalabekov A.L. 2017. Impact of the breed-specific characteristics on the metabolism and heavy metal accumulation in the organs and tissues of calves.Journal of Pharmaceutical Sciences and Research. 9. 6: 780-784.

8) Temiraev V.K., Kairov V.R., Temiraev R.B., Kubatieva Z.A., GukezhevV.M. 2017. Method to improve productive performance and digestion exchange of broiler chickens with reduced risk of aflatoxicosis.Ecology, Environment and Conservation. 23. №1: 554-561.

9) Temiraev R.B., Tedtova V.V., Baeva Z.T., Mosesyan L.R. 2011. Method to Improve Ecological and Nutritional Properties of Milk and Dairy Products in the Conditions of the Foothill Zone of the North Caucasus. Sustainable Development of Mountain Territories 7, no. 1: 97-104.

10) Temiraev R.B., Kozhokov M.K., Cherchesova S.K., Kokaeva F.F., Tletseruk I.R. 2017. Method for diminishing the adverse effect of anthropogenic heavy metal pollution on poultry meat products. Journal of Environmental Management and Tourism. 8. 3 (19): 567-573.

11) Temiraev V.H., Baeva A.A., Vityuk L.A., Mamukaev M.N., Yurina N.A., Ktsoeva I.I., Bobyleva L.A., Zagaraeva E.F., Kokov T.N., Vologirova F.A. 2020. Effect of probiotics on digestive metabolism in growing and laying poultry birds. Journal of Livestock Science 11: 33-39.

12) Tsalieva L.V., Temiraev R.B., Kononenko S.I., Dzagurov B.A., Gazzaeva M.S., Grevtsova S.A. 2017. Ecological and consumer properties of pig meat from different breeds produced in technogenic zone.Journal of Pharmaceutical Sciences and Research. 9(12): 2397-2400.

13) Vityuk L.A., Kokaeva M.G., Baeva Z.T., Tedtova V.V. 2012. Technological method of increasing consumer qualities of milk and dairy products.Sustainable development of mountain areas. 4: 81-84.

14) Yuldashbaev Y.A., Temiraev R.B., Tedtova V.V., Temiraev K.B.,Osikina R.V., Gazzaeva M.S., Shugusheva L.H., Sattsaeva I.K., Udychak M.M. 2020. Control of physical and chemical qualities of milk and dairy food products obtained in an ecologically unfavorable zone. Journal of Livestock Science 11: 8-13 doi. 10.33259/JLivestSci.2020.8-13. 